УДК $615.322 .074: 547.586 .5: 582.933$

\title{
ОПРЕДЕЛЕНИЕ СОДЕРЖАНИЯ ГИДРОКСИКОРИЧНЫХ КИСЛОТ В ЛИСТЬЯХ ПОДОРОЖНИКОВ БОЛЬШОГО (PLANTAGO MAJOR L.) И СРЕДНЕГО (PLANTAGO MEDIA L.)
}

\author{
(C) Т.В. Хортецкая, Г.П. Смойловская", А.В. Мазулин, Г.В. Мазулин
}

Запорожский государственный медицинский университет, пр. Маяковского, 26, Запорожье, 69035 (Украина), e-mail: smoilovskaj@ukr.net

Методом тонкослойной хроматографии установлен качественный состав гидроксикоричных кислот в листьях подорожника большого и подорожника среднего. Проведено сравнительное спектрофотометрическое определение суммы орто-дигидрокоричной кислоты и хлорогеновой кислоты в исследуемых видах.

Ключевые слова: виды рода подорожник, гидроксикоричные кислоты, актеозид, хлорогеновая кислота.

\section{Введение}

Крупнейшим родом семейства Plantaginaceae Juss. является род Plantago L., который включает около 275 видов однолетних и многолетних трав и полукустарников, распространенных во всем мире [1, 2].

Широкое использование в традиционной и народной медицине видов рода Plantago L .обусловлено наличием разнообразных целебных свойств: кровоостанавливающих, противомикробных, отхаркивающих, вяжущих, мочегонных и успокаивающих. Кроме того, исследования последних лет подтверждают, что некоторые виды подорожника проявляют противовоспалительное, иммунорегулирующее, антиоксидантное, цитотоксическое действие [2, 3].

Проведенные исследования указывают на высокую перспективность растений для применения в медицине в качестве источника биологически активных соединений. Одноко большинство из представителей рода Plantago L. не описаны с точки зрения фитохимического состава и биологической активности. Важным остается и вопрос об определении маркеров, характеризующих фармакологическую активность растений и препаратов на его основе.

Исследования, проведенные I.N. Beara с соавт., подтверждают наличие высокой антиоксидантной, противовоспалительной и цитотоксической активности Plantago altissima L. и Plantago lanceolata L. Доказано наличие связи между фармакологической активностью и содержанием в растительном сырье фенольных соединений, в том числе гидроксикоричных кислот [3].

Хортецикая Тая Владимировна - ассистент кафедры фармакогнозии, фармацевтической химии и технологии лекарств, тел.: +380 612 34-23-31

Смойловская Галина Павловна - старший преподаватель кафедры фармакогнозии, фармацевтической химии и технологии лекарств, тел.: +380612 34-23-31, e-mail: smoilovskaj@ukr.net Мазулин Александр Владленович - заведующий кафедрой фармакогнозии, фармацевтической химии и технологии лекарств, доктор фармацевтических наук, профессор, тел.: +380 612 34-23-31

Мазулин Георгий Владленович - ассистент кафедры фармакогнозии, фармакологии и ботаники, тел.: +380 612 34-23-31
N. Rønsted c соавт. предлагают использование в качестве маркеров рода подорожник иридоидов и гидроксикоричных кислот (caffeoyl phenylethanoid glycosides) как основных действующих компонентов [4].

В отечественной и зарубежной нормативной документации содержание гидроксикоричных кислот стандартизируется в лекарственном сырье артишока, крапивы двудомной, мелиссы лекарственной и др. [5]. Государственная фармакопея Украины 1-го издания в статье «Подорожника большого листья» регламентирует определение содержания суммы производных ортодигидрокоричных кислот в перерасчете на актеозид [6].

\footnotetext{
* Автор, с которым следует вести переписку.
} 
Гидроксикоричные кислоты являются наиболее распространенными полифенольными кислотами высших растений, которые проявляют в экспериментах антиоксидантные, антирадикальные свойства, обладают иммуностимулирующей, противовирусной и противовоспалительной активностью [4, 7-9].

Цель нашей работы - изучение содержания гидроксикоричных кислот в листьях фармакопейного вида подорожника большого (Plantago major L.) и филогенетически близкого к нему вида подорожника среднего (Plantago media L.).

\section{Экспериментальная часть}

В качестве объектов исследования использовали листья подорожника (п.) большого (Plantago major L.), п. среднего (Plantago media L.), собранные в различных регионах Украины в период интенсивного цветения в июне - июле 2010-2011 гг.

Сбор сырья проводился по общепринятым методикам. Сушка листьев осуществлялась в сушильном шкафу при температуре $50{ }^{\circ} \mathrm{C}$.

Для качественного определения гидроксикоричных кислот использовали реакцию с 3\% раствором хлорида железа (III) на 50\% спиртовый экстракт воздушно-сухого сырья (1 : 5), измельченного до диаметра 1-2 мм.

При идентификации гидроксикоричных кислот полученный экстракт сгущали и подвергали хроматографическому разделению на пластинках Sorbfil АФ-А. В качестве системы растворителей использовали этилацетат - этиловый спирт (95: 5) и уксусную кислоту $15 \%$. Детектирование веществ на хроматограммах проводили по флуоресценции в УФ-свете до и после обработки парами гидроксида аммония и диазореактива, а также по сравнительным значениям Rf со стандартными образцами.

Количественное содержание суммы орто-дигидроксикоричных кислот в сырье определяли спектрофотометрическим методом. Для этого 1,0 г сырья (точную навеску) измельчали до диаметра 1 мм, помещали в колбу и добавляли 100 мл $50 \%$ этилового спирта, нагревали на водяной бане с обратным холодильником в течение 1 ч. После охлаждения фильтровали в мерную колбу на 100 мл, доводили до метки спиртом (раствор 1).

1 мл раствора 1 помещали в мерную колбу на 10 мл и добавляли 2 мл 0,5 М раствора хлористоводородной кислоты, 2 мл раствора 2 и 2 мл раствора гидроксида натрия. Полученный раствор доводили очищенной водой до метки. Обязательным условием являлось перемешивание после каждого добавления реагентов. Раствор 2 готовили разведением 10 мл нитрита натрия и 10 г натрия молибденовокислого в 100 мл очищенной воды.

В качестве компенсационного использовали раствор, содержащий 1 мл раствора 1, 2 мл 0,5 M раствора хлористоводородной кислоты, 2 мл раствора гидроксида, доведенный водой очищенной до метки.

Оптическую плотность определяли сразу после приготовления исследуемого и компенсационного раствора при длине волны 525 нм на спектрофотометре Specord-200 Analytic Jena UV-vis. Расчет содержания проводили по формуле:

$$
\mathrm{X}=\frac{A \cdot 10000}{185 \cdot m}
$$

где $A$ - оптическая густота исследуемого раствора при длине волны 525 нм; $m$ - масса навески сырья, г; 185 - удельный показатель поглощения стандартного образца актеозида при волны 525 нм.

Количественное содержание хлорогеновой кислоты проводили по разработанной нами методике с использованием полученного ранее раствора 1. 1 мл данного раствора помещали в мерную колбу на 10 мл, доводили до метки 50\% этиловым спиртом. Оптическую плотность определяли при длине волны 327 нм.

В качестве стандартного образца использовали 50\% спиртовой раствор стандарта хлорогеновой кислоты фирмы Aldrich Lot SLBF3987V (содержание >95 \%).

\section{Результаты и их обсуждение}

При проведении химических реакций на гидроксикоричные кислоты, во всех растворах появлялось сине-зеленое окрашивание раствора различной интенсивности, свидетельствовавшее о присутствии в исследуемых образцах данных веществ.

При проведении тонкослойной хроматографии детектирование в УФ-свете до и после обработки парами аммония гидроксида и диазореактива показало наличие 4 веществ, которые в УФ-свете имели светлоголубую или голубую флюоресценцию, а после обработки парами аммония гидроксида свечение менялось на зеленое и желто-зеленое, что является характерным для класса гидроксикоричных кислот. После обработки хроматограмм диазореактивом пятна приобретали окраску от желто-коричневой до коричневой. 
По характерному свечению в УФ-свете, величине Rf, окраске пятен после проявления парами аммония гидроксида и диазореактива, а также при сравнении с образцами кислоты хлорогеновой (фирма Aldrich Lot SLBF3987V, содержание >95\%), неохлорогеновой (фирма Sigma Lot BCBK2340V, содержание >98\%) и литературными данными в исследуемых образцах достоверно обнаружено присутствие хлорогеновой и неохлорогеновой кислот; предположительно - актеозида, плантамайозида.

При спектрофотометрическом определении суммы производных орто-дигидроксикоричных кислот расчет содержания производился в пересчете на актеозид при длине волны 525 согласно методике Государственной фармакопеи Украины 1-го издания [6].

Анализ УФ-спектров показывает присутствие на всех хроматограммах максимума поглощения при длине волны 510 нм и плеча при 525 нм (рис. 1), что позволяет предположить присутствие в изученном лекарственном сырье помимо актеозида других гидроксикоричных кислот.

Так как при проведении предварительных исследований с помощью ТСХ достоверно идентифицирована хлорогеновая кислота, нами разработана методика ее спектрофотометрического определения с использованием стандартного образца (рис. 2).

Полученные данные определения суммы орто-дигидрокоричных кислот и хлорогеновой кислоты в листьях п. большого и п. среднего представлены в таблице.

Установлено большее содержание суммы орто-дигидроксикоричных кислот в листьях п. большого (до 1,616 $0,035 \%$ ). Меньшее количество гидроксикоричных кислот характерно для листьев п. среднего (до $1,518 \pm 0,028 \%)$. Полученные данные коррелируются с накоплением в исследуемом сырье хлорогеновой кислоты. Концентрация данной гидроксикоричной кислоты в листьях п. большого колеблется от

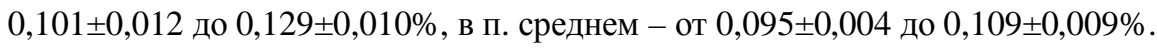

Анализ полученных данных свидетельствует о возможности использования данных методик для определения содержания гидроксикоричных кислот в лекарственном сырье видов рода подорожник.

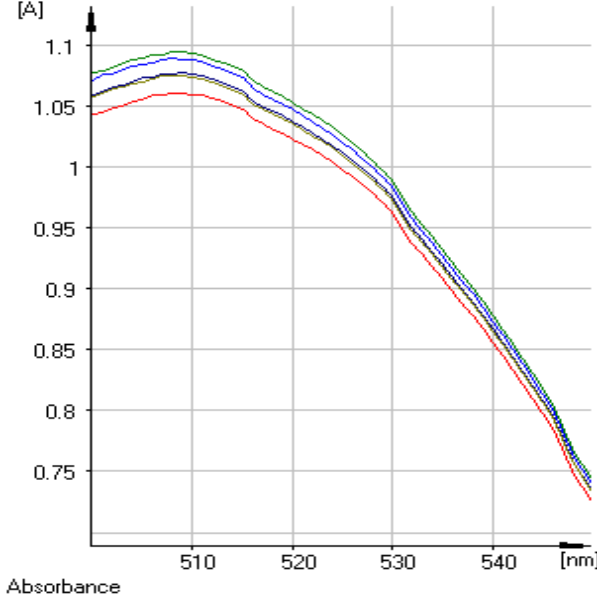

Рис. 1. УФ-спектр 50\% спиртового экстракта листьев подорожника большого (1:100)

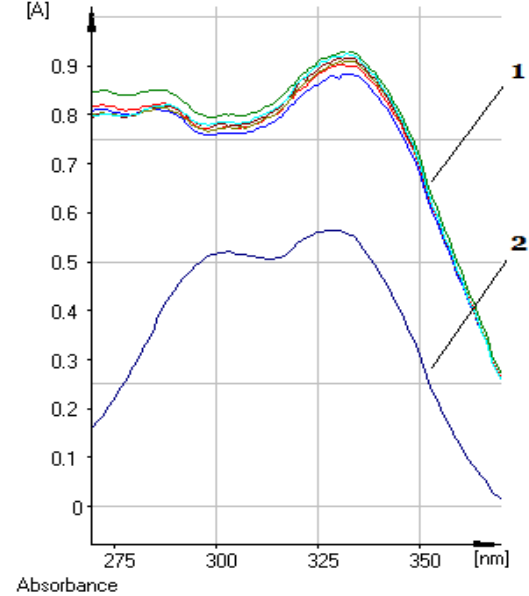

Рис. 2. УФ-спектр 50\% спиртового экстракта листьев подорожника большого (1: 100) - I; раствор стандартного образца хлорогеновой кислоты (фирма Aldrich Lot SLBF3987V) (10 мкг/мл) - II

Количественное содержание гидроксикоричных кислот в листьях Plantago major L. и Plantago media L. флоры Украины ( $\overline{\mathrm{x}} \pm \Delta \overline{\mathrm{x}} \%), \mu=6$

\begin{tabular}{c|l|c|c}
\hline \multirow{2}{*}{$№$} & \multicolumn{1}{|c}{ Место заготовки } & \multicolumn{2}{|c}{ Содержание } \\
\cline { 3 - 4 } & & \multicolumn{1}{|c}{$\begin{array}{c}\text { сумма } 0 \text {-дигидрокси- } \\
\text { коричных кислот }\end{array}$} & хлорогеновая кислота \\
\hline 1 & П. большой, Симферополь АР Крым, 05.07.2011 & $1,551 \pm 0,069$ & $0,110 \pm 0,012$ \\
2 & П. большой, г. Орехов, Запорожская обл., 01.07.2010 & $1,593 \pm 0,042$ & $0,120 \pm 0,013$ \\
3 & П. большой, г. Новотроицкое, Херсонская обл., 05.07.2011 & $1,616 \pm 0,035$ & $0,129 \pm 0,010$ \\
4 & П. средний, г. Васильевка, Запорожская обл., 02.08.2010 & $1,176 \pm 0,039$ & $0,095 \pm 0,004$ \\
5 & П. средний, п.г.т. Кушугум, Запорожская обл., 03.08.11 & $1,253 \pm 0,027$ & $0,101 \pm 0,010$ \\
6 & П. средний, г. Дружковка, Донецкая обл., 01.07.10 & $1,518 \pm 0,028$ & $0,109 \pm 0,009$ \\
\hline
\end{tabular}




\section{Выводы}

В результате проведенных исследований методом ТСХ достоверно идентифицированы хлорогеновая и неохлорогеновая кислоты. Методом спектрофотометрии определены сумма о-дигидроксикоричных кислот, а также содержание хлорогеновой кислоты в подорожнике большом и п. среднем. Результаты качественного и количественного определения подтвердили систематическую близость между п. большим и П. средним. Полученные данные показывают возможность использования п. среднего в качестве дополнительного источника лекарственного растительного сырья к официальному виду подорожника большого и перспективность их использования в фармацевтической промышленности.

\section{Сиисок литературы}

1. Rønsted N., Franzyk H., Mølgaard P., Jaroszewski1 J.W., Jensen S.R. Chemotaxonomy and evolution of Plantago L. // Plant Syst. Evol. 2003. Vol. 242. Pp. 63-82.

2. Olennikov D.N., Samuelsen A.V., Tankhaeva L.M. Khimiia rastitel'nogo syr'ia, 2007, no. 2, pp. 37-50. (in Russ.).

3. Beara I.N., Lesjak M.M., Orčić D.Z., Simin N.Đ., Četojević-Simin D.D., Boźin B.N., Mimica-Dukić N.M. Comparative analysis of phenolic profile, antioxidant, anti-inflammatory and cytotoxic activity of two closely-related Plantain species: Plantago altissima L. and Plantago lanceolata L. // LWT - Food Science and Technology. 2012. Vol. 47. Pp. 64-70.

4. Rønsted N., Göbel E., Franzyk H., Jensen S.R., Olsen C.E. Chemotaxonomy of Plantago. Iridoid glucosides and caffeoyl phenylethanoid glycosides // Phytochemistry. 2000. N55. Pp. 337-348.

5. Медведьев Ю.В., Передеряев О.И., Арзамасцев А.П., Эллер К.И., Прокофьева В.И. Определение гидроксикоричных кислот в лекарственном растительном сырье и объектах растительного происхождения // Вопросы биологической, медицинской и фармацевтической химии. 2010. №3. С. 25-31.

6. Державна Фармакопея України. Доповнення 3. Харків, 2009. С. 202-205.

7. Брыкалов А.В., Головкина Е.М., Белик Е.В., Бостанова Ф.А. Исследование физиологически активных соединений в препарате из эхинацеи пурпурной // Химия растительного сырья. 2008. №3. С. 89-91.

8. Мельник О.А., Унгурян Л.М. Пошук лікарських засобів на основі рослинної сировини, що містять кислоту хлорогенову // Фармацевтичний часопис. 2011. №1. С. 90-94.

9. Левицкий А.П., Вертикова Е.К., Селиванская И.А. Хлорогеновая кислота: биохимия и физиология // Мікробіологія і біотехнологія. 2010. №2. С. 6-20.

Поступило в редакиию 28 мая 2013 г.

Khortetskaya T.V., Smoylovskaya G.P.*, Mazulin A.V., Mazulin G.V. DETERMINATION OF HYDROXYCINNAMIC ACIDS IN LEAVES OF PLANTAIN PLANTAGO MAJOR L. AND PLANTAGO MEDIA L.

Zaporozhye State Medical University, Maiakovskogo ave., 26, Zaporozhye, 69035 (Ukraine), e-mail: smoilovskaj@ukr.net

By the method of thin layer chromatography is set the qualitative composition of hydroxycinnamic acids in the leaves of plantain Plantago major L. and Plantago media L. A comparative spectrophotometric determination of ortodihydrocennamic acid and chlorogenic acid amount has carried out in studied species.

Keywords: species of the genus of plantain, hydroxycinnamic acids, akteozid, chlorogenic acid.

\section{References}

1. Rønsted N., Franzyk H., Mølgaard P., Jaroszewski1 J.W., Jensen S.R. Plant Syst. Evol., 2003, vol. 242, pp. 63-82.

2. Olennikov D.N., Samuelsen A.V., Tankhaeva L.M. Khimiia rastitel'nogo syr'ia, 2007, no. 2, pp. 37-50. (in Russ.).

3. Beara I.N., Lesjak M.M., Orčić D.Z., Simin N.Đ., Četojević-Simin D.D., Boźin B.N., Mimica-Dukić N.M. $L W T$ Food Science and Technology, 2012, vol. 47, pp. 64-70.

4. Rønsted N., Göbel E., Franzyk H., Jensen S.R., Olsen C.E. Phytochemistry, 2000, no. 55, pp. 337-348.

5. Medved'ev Iu.V., Perederiaev O.I., Arzamastsev A.P., Eller K.I., Prokof'eva V.I. Voprosy biologicheskoi, meditsinskoi i farmatsevticheskoi khimii, 2010, no. 3, pp. 25-31. (in Russ.).

6. Derzhavna Farmakopeja Ukrai'ny. Dopovnennja 3. [Pharmacopoeia of Ukraine]. Kharkiv, 2009, pp. 202-205. (in Ukr.).

7. Brykalov A.V., Golovkina E.M., Belik E.V., Bostanova F.A. Khimiia rastitel'nogo syr'ia, 2008, no. 3, pp. 89-91. (in Russ.).

8. Mel'nyk O.A., Ungurjan L.M. Farmacevtychnyj chasopys, 2011, no. 1, pp. 90-94. (in Ukr.).

9. Levitskii A.P., Vertikova E.K., Selivanskaia I.A. Mikrobiologija i biotehnologija, 2010, no. 2, pp. 6-20. (in Russ.).

\footnotetext{
* Corresponding author.
} 